\title{
8
}
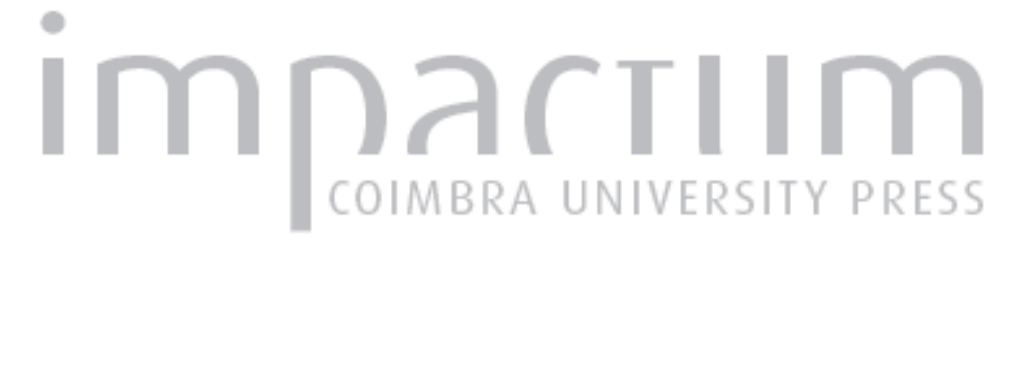

\section{O aqueduto do Convento de Cristo, em Tomar: análise preliminar da estrutura} hidráulica

\author{
Autor(es): $\quad$ Antunes, Tiago Molarinho
}

Publicado por: Faculdade de Letras da Universidade de Coimbra, Instituto de História Económica e Social

URL persistente:

URI:http://hdl.handle.net/10316.2/29873

DOI:

http://dx.doi.org/10.14195/0870-4147_43_13

Accessed : $\quad$ 26-Apr-2023 13:06:58

A navegação consulta e descarregamento dos títulos inseridos nas Bibliotecas Digitais UC Digitalis, UC Pombalina e UC Impactum, pressupõem a aceitação plena e sem reservas dos Termos e Condições de Uso destas Bibliotecas Digitais, disponíveis em https://digitalis.uc.pt/pt-pt/termos.

Conforme exposto nos referidos Termos e Condições de Uso, o descarregamento de títulos de acesso restrito requer uma licença válida de autorização devendo o utilizador aceder ao(s) documento(s) a partir de um endereço de IP da instituição detentora da supramencionada licença.

Ao utilizador é apenas permitido o descarregamento para uso pessoal, pelo que o emprego do(s) título(s) descarregado(s) para outro fim, designadamente comercial, carece de autorização do respetivo autor ou editor da obra.

Na medida em que todas as obras da UC Digitalis se encontram protegidas pelo Código do Direito de Autor e Direitos Conexos e demais legislação aplicável, toda a cópia, parcial ou total, deste documento, nos casos em que é legalmente admitida, deverá conter ou fazer-se acompanhar por este aviso.

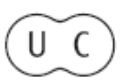





\title{
O Aqueduto do Convento de Cristo, em Tomar. Análise Preliminar da Estrutura Hidráulica*
}

\author{
Tiago Molarinho Antunes \\ Instituto de História de Arte, Faculdade de Ciências Sociais e Humanas \\ da Universidade Nova de Lisboa \\ tmolarinho@gmail.com
}

Resumo:

O aqueduto do Convento de Cristo, em Tomar é iniciado na última década do século XVI e os trabalhos da sua construção estendem-se até 1619 , data da inauguração deste aqueduto, presenciada por D. Filipe II de Portugal. Este estudo apresenta uma breve sinopse histórica, enunciando a logística da execução do sistema hidráulico do conjunto tomarense, referenciando os profissionais envolvidos e os materiais empregues em obra.

Através do trabalho de campo de levantamento arquitectónico realizado em 2009 [O Aqueduto do Convento de Cristo, em Tomar. Bases para uma proposta de Salvaguarda e Valorização, dissertação de mestrado, Évora, Universidade de Évora, 2009], podemos aqui fundamentar as características intrínsecas com que esta estrutura interage com o território, os tipos de captação hidráulica e a forma de condução da água em todo o traçado. Ao mesmo tempo analisamos as opções arquitectónicas da construção, os edifícios que o completam, as preocupações com a depuração da água e a interacção com a actividade do vale e os seus recursos hídricos.
Abstract:

The construction of the aqueduct of the Convent of Christ in Tomar started in the last decade of the 16th century and the works continued until 1619, when it was inaugurated in the presence of King Philip II of Portugal. This study presents a brief historical synopsis, explaining the logistics of implementation of the hydraulic system of the Tomar complex, mentioning the professionals involved and the building materials used in the work.

Using the results of the field work of architectural survey done in 2009 , we here can explain the intrinsic characteristics that allow this structure to interact with the territory, the types of catchment and forms of driving the water throughout the whole network. At the same time, we analyze the architectural options of the construction, the buildings that serve as complement, the concerns with water purification, and the interaction with the activity of the valley and its water resources.

Keywords:

Tomar; Convent of Christ; Filipe Terzi; Aqueduct; Hydraulics.

Palavras chave:

Tomar; Convento de Cristo; Filipe Terzi; Aqueduto; Hidráulica.

* O autor manifesta agradecimento a todas as pessoas que participaram neste estudo, em especial ao Professor Doutor Virgolino Ferreira Jorge, orientador da dissertação de mestrado, cujo apoio contínuo e presente, permitiu realizar o contributo que aqui apresenta. 


\section{Contexto da morfologia do sítio}

O conjunto situa-se dentro das freguesias de Carregueiros e de S. João Baptista, a noroeste do concelho de Tomar, no distrito de Santarém. As suas coordenadas geográficas são $8^{\circ} 25$ e $8^{\circ} 28$ com longitude W e $39^{\circ} 36$ e $39^{\circ} 38$ de latitude $\mathrm{N}^{1}$.

A morfologia deste território é composta pela intercepção de um conjunto de vales pouco profundos, onde a variação altimétrica regista os valores de 50 a $225 \mathrm{~m}^{2}$. Estes valores definem uma volumetria decrescente, em convergência com os vales, de norte para sul, sendo o vale dos Pegões o ponto de distribuição. São constantes os relevos calcários, cuja cor esbranquiçada é claramente distinta da paisagem envolvente, "repleta de uma vegetação mediterrânea de carrasco, lentisco, aroeira, zambujo e ervas perfumadas que cobre o solo"3, mais ou menos presente, dependendo do abandono das terras. Este tipo de morfologia territorial integra a estrutura fundamental do relevo da zona Centro, interligando a paisagem atlântica da orla litoral, com o interior da bacia do Tejo.

Em termos litológicos, predomina claramente o calcário, verificando-se a predominância de rochas detríticas, a par com grande quantidade de seixo e cascalho, aparentemente, vestígios do período jurássico, onde a "região de Tomar foi parte integrante de um grande mar interior" ${ }^{\text {. O }}$ solo é de um modo geral de cariz mediterrânico avermelhado, também presente em alguns afloramentos rochosos, o que confirma a quantidade de argila aqui existente.

A ocupação e a rendibilidade dos solos nesta região apresentam uma variedade no dimensionamento das parcelas, definida em parte, pelo relevo e localização. As parcelas de maior dimensão, localizadas em zonas mais altas, são menos férteis e o seu uso é intensamente ocupado pela cultura do eucalipto. Em menor quantidade, algumas destas parcelas são ocupadas para pasto e por pomares de figueira e olivais. Nas zonas médias, onde o solo já apresenta riqueza, verifica-se o povoamento florestal do pinheiro, eucalipto, olivais e

1 As coordenadas aqui referidas correspondem à rede GEODÉSICA WGS84 e estão registadas na parte ocidental da Carta Militar de Portugal do Instituto Geográfico do Exército, Escala 1:25 000, Série M888, Folha 310 (Tomar), Edição 4 - IGE - 2003.

2 A este propósito, ver em apêndice, Ilustração 1.

3 VVAA, Contributos para a identificação e caracterização da paisagem em Portugal Continental, Volume III, Grupos de Unidades de Paisagem 67 (Estremadura) e (Pinhal Centro), Direcção Geral do Ordenamento do Território, Lisboa, 2003, p. 9.

4 Álvaro José Barbosa, Os Sete Montes de Tomar. Recuperação da cerca do Convento de Cristo, Casal de Cambra, Caleidoscópio, Setembro de 2003, p. 15. 
alguns vinhedos. Nas zonas baixas, há um território rico em recursos hídricos, essencialmente ocupado por horta ${ }^{5}$.

O povoamento deste espaço caracteriza-se pela dispersão de pequenos aglomerados, maioritariamente localizados junto a acessos viários, como a aldeia de Carregueiros e o lugar de Brasões.

\section{Breve resenha histórica da construção do aqueduto}

O arranque da construção do aqueduto do Convento, pelas mãos do arquitecto do Reino, Filipe Terzi, nomeado mestre das obras do Convento de Cristo, a 22 de Janeiro de 1584, ocorreu no reinado de D. Filipe I de Portugal. No cargo sucedeu-lhe Francisco Lopes ${ }^{6}$, até à data do seu falecimento, em 1597. A continuidade dos trabalhos foi adjudicada a Pero Fernandes de Torres, arquitecto do Convento e autor do traço da fonte do claustro dos Filipes ${ }^{7}$.

Os pedreiros envolvidos na construção do aqueduto são em grande número. A sua actividade surge-nos em nome individual e em sociedades de dois, três ou mais indivíduos. Salientamos dois deles, Salvador Jorge e Pêro Antunes, pela continuidade no fornecimento de varas de canalização, lajes e silhares, a quem foram feitas quatro adjudicações. $\mathrm{O}$ primeiro surge numa fase da obra do troço aéreo nos Pegões $^{8}$ e o segundo, está referenciado desde 28 de Outubro de 1595 até 1600 , na realização das arcas das fontes, nascentes e edifícios.

A adjudicação de contratos para a realização da obra ocorreu de igual forma, consoante as necessidades de matéria-prima, sendo exemplo a encomenda de cal a Fernão Jorge e a Simão Fernandes, em 15 de Fevereiro de 1597. Entre carpinteiros, ferreiros, caeiros, cabouqueiros, serventes, e outros operários especializados e aprendizes, foram diversas as pessoas e profissões ligadas à obra do aqueduto.

Os registos da construção revelaram-nos os dados de uma grande máquina de manufactura e prestação de serviços. Os grandes contratos realizados para o fornecimento de canos e respectiva cobertura, bem como a silharia necessária

5 Toda esta zona é ainda pontuada por diversas estruturas arquitectónicas, como presas, canais e poços, desenhando no território que ocupam um sistema de rentabilização dos recursos hídricos inerentes.

${ }^{6}$ Cf. Sousa Viterbo, Dicionário Histórico e Documental dos Arquitectos, Engenheiros e Construtores Portugueses, Volume III, Lisboa, Imprensa Nacional Casa da Moeda, p. 96.

7 Gustavo de Matos Sequeira, Inventário Artístico de Portugal, Distrito de Santarém, volume III, Lisboa, Academia Nacional de Belas Artes, 1949, p. 107.

8 Ernesto José Nazaré Alves Jana, "O Aqueduto dos Pegões - subsídios para o seu estudo", Boletim Cultural, Câmara Municipal de Tomar, Outubro de 1992, p. 98. 
à construção dos troços aéreos, são encomendas enormes realizadas nos três primeiros anos. Os cabouqueiros e serventes entram numa fase mais avançada das obras, por volta de 1597, época em que grande parte das encomendas de canalização e respectivas coberturas em laje já estavam entregues ou em curso.

A aquisição dos terrenos de atravessamento do aqueduto e das nascentes de água está referenciada em $1595^{9}$, o que nos revela os inícios da construção. Esta situação comprova-nos que os trabalhos do traçado e as questões relacionadas com o seu funcionamento deverão ter sido estudadas e iniciadas no ano de $1593^{10}$. Entre 1595 e 1600 , assistimos a uma imensa actividade de compra de materiais de construção, como a pedraria ordinária, o saibro e a cal. Ao mesmo tempo, verifica-se a compra de um pinhal ${ }^{11}$ para extração de madeira para construção e encomendas de cantaria em canos para a condução da água, silhares para a construção de troços aéreos e execução das casas de água ${ }^{12}$, nascentes e casas de decantação, de aduelas para os remates dos vãos de acesso ao interior das construções associadas ao aqueduto.

Embora durante os primeiros três anos se verifique um grande número de encomendas de material para a construção do aqueduto, a continuidade da sua execução estende-se para lá deste período, nomeadamente com a execução das casas de água em 1600. A partir 1601, a par com o desenvolvimento da obra, assiste-se a pequenos trabalhos de remates, como os da casa da água a jusante dos Pegões, realizados por Pêro Marinho, ou a colocação de ferragens nas portas de madeira e respectivo envernizamento. A fase final é marcada pelo pagamento dos operários e serventes. Salientamos a encomenda a Mateus Fernandes do modelo do aqueduto, pela quantia de $2 \$ 000$ Reis $^{13}$.

Verifica-se que as encomendas de matérias-primas acontecem com uma ordem estabelecida. Após $1597^{14}$, com a maior parte dos canos já entregue em obra, ocorreu uma nova encomenda de cal, a par com os canos, os silhares e

9 Ernesto José Nazaré Alves Jana, “O Aqueduto dos Pegões ...”, cit., p. 95.

${ }^{10}$ Como refere na placa comemorativa, afixada no alçado norte da casa de água a jusante dos Pegões: "O Invictissimo e Muito Catholico Rei I D. Philippe I do nome e da Pia Venera I vel memoria com real liberdade I mandou fazer este aqueduto em I o anno de mil quinhentos e 93 I com a mesma o Agustissismo e Chris I tianismo Rei D. Philippe seu fi llho segundo do nome o fez acabar 1613".

${ }^{11}$ Ernesto José Nazaré Alves Jana, “O Aqueduto dos Pegões ...”, cit., p. 96.

${ }^{12}$ Esta designação surge-nos nos documentos consultados, referenciando-se às casas de decantação e fresco que ladeiam as extremidades do troço aéreo do vale da ribeira do Choupal, vulgarmente chamado de vale dos Pegões.

${ }^{13}$ Ernesto José Nazaré Alves Jana, “O Aqueduto dos Pegões ...”, cit., p. 99.

${ }^{14}$ Idem, ibidem, p. 98. 
o saibro e com os trabalhos dos cabouqueiros, serventes e operários, pois em 1598 iniciam-se as indemnizações dos proprietários por onde o aqueduto passa.

Segundo a inscrição na placa comemorativa ${ }^{15}$, afixada na casa de água a jusante dos Pegões, o conjunto do aqueduto já funcionava até este sítio, em 1613. Um ano depois, é a altura em que o aqueduto chega ao interior da cerca na Cadeira d'El Rei. Os troços superficiais e aéreos atingem a fachada sul do Convento, em 1617. O remate desta estrutura hidráulica faz-se com a ligação aos tubos que integram a fonte do claustro dos Filipes, desenhada por Pero Fernandes de Torres ${ }^{16}$. A inauguração do aqueduto do Convento de Cristo terá ocorrido com a presença de D. Filipe II de Portugal, que chegou a Tomar em Outubro de $1619^{17}$.

\section{Traçado do aqueduto}

O objecto em estudo compreende a estrutura arquitectónica de suporte e nivelamento do sistema hidráulico do aqueduto. O seu comprimento linear é cerca de $6.223 \mathrm{~km}$. A inserção deste sistema hidráulico no território ${ }^{18}$ tem início a 153,43 m de altitude a montante, na nascente do cano ${ }^{19}$, e termina a $127,15 \mathrm{~m}$ de altitude, a jusante, no ponto de intersecção com a cobertura do edifício conventual, vencendo desta forma 26,28 metros de desnível. Sob o princípio da força gravítica, o aqueduto do Convento de Cristo, mantém em quase toda a sua extensão um declive de montante para jusante com inclinações que variam entre $0,2 \%$ e $1,5 \%{ }^{20}$.

${ }^{15}$ Ver nota 10 deste artigo.

${ }^{16}$ Gustavo de Matos Sequeira, Inventário ..., cit., p. 107.

${ }^{17}$ Ernesto José Nazaré Alves Jana, cit.,p. 103.

${ }^{18}$ A marcação da intersecção do aqueduto no terreno realizou-se através de um trabalho de campo que contou com o apoio de duas cartas topográficas a 1:10000 (datadas de 2000), seis cartas de cadastro a 1:2000 (datadas de 1965), quatro ortofotomapas a 1:10000 (datadas de 2004) e quatro fotografias aéreas (datadas de 1957), todas nos formatos digital e em papel. O trabalho de campo teve o apoio de alguns habitantes desta região, o que se revelou de máxima importância no reconhecimento de alguns troços não identificados, bem como na identificação de algumas zonas inacessíveis visualmente e por consequência desconhecidas do público. O cruzamento das informações recolhidas permitiu a construção actualizada de todo o trajecto do aqueduto, em suporte digital (a este propósito, ver Ilustração 1 e 2).

${ }^{19}$ Tendo em conta que a nascente é soterrada, a cota referida corresponde à medida apurada no seu interior, sendo que a mesma cota à superfície corresponde a 156,43 m de altitude acima do nível do mar.

${ }^{20}$ A este propósito, ver em apêndice, Tabela 1 e Ilustração1. 
Numa análise de conjunto $^{21}$, verifica-se que a sua implantação esclarece um trajecto planeado, tanto na sua fixação ao lado direito do vale da ribeira do Choupal, como nas opções tomadas nos três tipos de troços existentes, subterrâneos, superficiais e aéreos. Este projecto é revelado no aproveitamento que a construção faz das características morfológicas do terreno, no trajecto superficial, manifesto na sua adaptação às curvas de nível do território que atravessa. Os troços soterrados e aéreos são, antes de mais, uma solução que visa alcançar o menor percurso linear na sua extensão, revelando uma ponderação continua nas opções do traçado, reduzindo sempre que possível o volume de construção $0^{22}$.

A leitura dos valores do declive permitem-nos uma análise clara da forma como a adução funciona. Assim, verificamos que nas zonas A, B, C e D, onde estão situadas as nascentes, o declive é mais acentuado, produzindo uma maior velocidade do caudal, atenuada nas zonas com $0,2 \%$ de declive ${ }^{23}$.

O caso mais díspar da inspecção realizada ao conjunto do traçado do aqueduto situa-se na zona $\mathrm{C}$ que, embora apresente na sua extensão linear o valor médio de $0,6 \%$ de declive, tem no seu primeiro troço aéreo ${ }^{24} \mathrm{o}$ maior declive, com 6,5\%, referentes à transição da cota de $145 \mathrm{~m}$ para $135 \mathrm{~m}$, vencendo $10 \mathrm{~m}$ de altitude em 153 m lineares de conduta superficial e aérea ${ }^{25}$.

Salientamos ainda que todo o conjunto interage com o funcionamento hídrico do território envolvente. A sua estrutura prevê zonas de passagem das linhas de água dos vales que atravessa, bem como vias de comunicação terrestres para pessoas e gado.

\section{Sistemas de captação de água potável}

O abastecimento hídrico deste sistema realiza-se através de quatro nascentes subterrâneas, com dois modos distintos de captação da água potável. Nas nascentes do Cano e da Pipa, a captação faz-se através da condução em mina,

${ }^{21}$ A par com o apoio dos documentos já referidos, executámos uma maqueta à escala de 1:5000, que se revelou determinante para a análise e entendimento do território circundante e opções tomadas quanto à implantação do traçado da conduta.

${ }^{22}$ A este propósito, ver em apêndice, Ilustração 1 e 2.

${ }^{23}$ Idem, ibidem, Tabela 1.

${ }^{24}$ Este troço aéreo, a 1.065,00 metros de distância em conduta, desde a nascente do Cano, é o primeiro a registar a imponente construção deste aqueduto no território. Com 153,00 metros de extensão, esta estrutura apresenta um suporte da canalização com 14 arcos de volta perfeita, à altura de $18 \mathrm{~m}$.

${ }^{25}$ A este propósito, ver em apêndice, Tabela 1 e Ilustração1. 
no enfiamento dos vales, sendo o freático alimentado pela infiltração da água dos ribeiros e pelas águas pluviais, através de bacias de retenção, construídas na mesma fileira. As nascentes do Cú-Alagado e da Porta-de-Ferro correspondem a mananciais de origem natural, e são escavadas na rocha ${ }^{26}$.

\section{Nascentes de captação por infiltração das linhas de água}

A nascente do $\mathrm{Cano}^{27}$ tem o seu topónimo ligado à tradição oral, pelo nome que o aqueduto adquire nesta parte do trajecto adutor. Está localizada no início do vale da ribeira do Choupal e tem uma profundidade de $3,00 \mathrm{~m}$. O poço de visita e de acesso à casa da nascente situa-se à cota de 156,43 m de altitude e a uma distância linear do dormitório do Convento de Cristo, de 4.621,00 m. A captação de água no subsolo, a 153,43 m de altitude, faz-se por um processo de drenagem por infiltração das águas acumuladas abaixo da superfície, na primeira linha de água, geradora da ribeira do Choupal. A planta da mãe-d'água é circular, com 4,44 m de diâmetro interior e 2,25 m de altura máxima. A sua volumetria interna corresponde a uma meia esfera ${ }^{28}$.

A mãe-d'água é interceptada por uma galeria, aberta em trincheira, a 0,45 m acima do seu pavimento, com 36,00 $\mathrm{m}$ de comprimento, 0,68 $\mathrm{m}$ de largura e $1,10 \mathrm{~m}$ de altura. $\mathrm{O}$ poço de acesso vertical possui a mesma largura da galeria, com uma secção de $0,90 \mathrm{~m}$ x $0,68 \mathrm{~m}$, e dista $1,92 \mathrm{~m}$ da referida casa da água. A mãe-d'água apresenta no pavimento um aparelhamento de grandes lajes de calcário. As paredes são de alvenaria de tijolo maciço e a cobertura, em abóbada hemisférica, está revestida por reboco.

A galeria adutora e o poço de acesso estão construídos com um aparelho maioritariamente de calcário. A argamassa de revestimento possui um preparado de cantaria, que lhe confere uma superfície quase lisa e permite uma melhor circulação de pessoas. A cobertura faz-se com lajes de calcário, assentes horizontalmente. A canalização, apoiada no solo, é executada com blocos de calcário, unidos nas extremidades com um encaixe macho-fêmea, devidamente argamassado, a fim de evitar perdas de água.

${ }^{26}$ A este propósito, ver o capítulo 1.3., intitulado "The water mines of Christ Convent aqueduct (Tomar)", de José Manuel Mascarenhas, Paul Benoit, Karine Berthier, Joséphine Rouillard and Virgolino Jorge, Comparative nalysis of Mines Supplying Water To Towns, To Abbeys And To Manors In Portugal (15 th.-18th. centuries), Schriftenreihe der Frontinus - Gesellschaft, 26, 2005, p. 207-222.

${ }^{27}$ Esta nascente tem igualmente o microtopónimo de Pote, devido à quantidade de água que armazena.

${ }^{28}$ A este propósito, ver em apêndice, Ilustração 1 e 3. 
A nascente da Pipa localiza-se no final de um vale (o vale da Pipa) e deve o seu nome à quantidade de água que outrora armazenava, quando o sistema ainda estava activo. Situa-se à cota de 153,27 $\mathrm{m}$ de altitude e a uma distância linear de 4.328,00 m do edifício conventual. A captação de água é realizada no subsolo, a 3,00 $\mathrm{m}$ de profundidade, por um processo de escoamento das águas superficiais, numa das linhas que alimentam a ribeira do Choupal. Esta recolha por infiltração provém de um conjunto de oito bacias de retenção de águas pluviais ${ }^{29}$, dispostas de modo transversal ao enfiamento do vale da Pipa ${ }^{30}$.

A nascente está protegida por uma pequena construção, parcialmente soterrada. A planta, de desenho oblongo, mede no seu interior $2,33 \mathrm{~m}$ de comprimento e 1,54 m de largura. As paredes foram executadas com um aparelho ordinário de alvenaria de pedregulho, devidamente rebocado. O interior da obra tem um pé direito máximo de $3,00 \mathrm{~m}$ e está coberto com uma abóbada de berço simples, construída com lajes de argila aparelhadas.

A mãe-d'agua é interceptada por uma galeria com 0,71 m de largura e uma altura de medida decrescente, variando entre $1,97 \mathrm{~m}$, na adjacência da casa e $0,80 \mathrm{~m}$, no poço de acesso vertical, afastado $31,00 \mathrm{~m}$ e à cota de $151,00 \mathrm{~m}$ de altitude. As dimensões deste poço são de 1,46 m x 0,95 m e uma profundidade de $3,52 \mathrm{~m}$. Na sua base apresenta uma caixa de decantação, que interliga o caudal proveniente das nascentes do Cano e da Pipa. O transporte da água faz-se em caleiras com uma secção transversal em $\mathrm{U}$, assentes no fundo da galeria.

\section{Nascentes de captação em mananciais de origem natural}

A nascente do Cú-Alagado deve a sua denominação local ao facto de adquirir esta configuração de acesso ao interior. Localiza-se a 153,27 m de altitude e está afastada 4.328,00 m em linha recta, do edifício conventual ${ }^{31}$.

Trata-se de uma pequena construção de abrigo da nascente natural, implantada maioritariamente no exterior. A estrutura arquitectónica tem a volumetria de um cubo, interceptado por um vão de acesso ao edifício e pela galeria adutora de água potável. O interior da obra tem uma planta de 2,56 m de largura e 2,26 de altura. As paredes são construídas em alvenaria ordinária de calcário rebocada. O remate da cobertura faz-se com uma abóbada hemisférica, igualmente de calcário e tijolo argamassados, à altura máxima de 3,44 m, no intradorso.

\footnotetext{
${ }^{29}$ Registado no local e revisto nas fotografias aéreas de 1957.

${ }^{30}$ A este propósito, ver em apêndice, Ilustração 1 e 4.

${ }^{31}$ A este propósito, ver em apêndice, Ilustração 1 e 5.
} 
A captação deste aquífero faz-se por mina escavada na rocha, sob o leito esquerdo do vale da ribeira do Choupal. O edifício tem um pequeno tanque de decantação (hoje obstruído), central ao espaço interno, onde desaguam os caudais da mina e da rede adutora vinda de montante. Ele serve também como casa de fresco, devido à existência de quatro bancos em consola. As paredes da galeria de adução da água para o convento são executadas em alvenaria de pedregulho aparelhado e a sua cobertura é feita com lajes de calcário.

A nascente da Porta-de-Ferro tem a sua designação microtoponímica associada à porta-de-ferro de acesso ao interior do edifício ${ }^{32}$. Situa-se no leito esquerdo do vale da ribeira do Choupal, a 141,78 m de altitude e à distância linear de 3.513,00 m do Convento de Cristo. O edifício apresenta uma implantação parcialmente encaixada no terreno e tem as dimensões interiores de $8,60 \mathrm{~m}$ de comprimento, 7,38 $\mathrm{m}$ de largura e 6,22 m de altura máxima. No alçado principal abrem-se duas janelas e no lateral direito, uma (hoje entaipadas). O alçado principal é ainda assinalado pela cobertura exterior, de duas águas, e pela marcação do frontão da porta ${ }^{33}$.

A captação da água é realizada por uma mina, que descarrega para o tanque de decantação, com forma trapezoidal e $2,10 \mathrm{~m}$ de profundidade ${ }^{34}$. Ainda no interior da casa, e embebida no pavimento, encontra-se a canalização de meia cana que transporta a água das três nascentes a montante e descarrega o fluxo também para o decantador. $\mathrm{O}$ tanque de decantação está provido de um descarregador de superfície, para obviar os inconvenientes devidos à obstrução eventual da caleira adutora. Uma comporta permite interromper o caudal da caleira no decantador, desviando-o para o exterior do edifício, mormente em casos de limpeza do tanque. Ainda no interior, regista-se em quase toda a extensão do alçado lateral direito, um banco corrido executado em alvenaria com lajes de argila no topo. Os materiais de construção utilizados neste edifício são a alvenaria de pedra ordinária argamassada, o calcário regular, a argila, a madeira e o ferro forjado.

${ }^{32}$ Designada pelos habitantes locais mais antigos também por nascente dos Frades (informação de António Serra, da Junta de Freguesia de Carregueiros).

${ }_{33}$ A este propósito, ver em apêndice, Ilustração 1 e 6.

${ }^{34}$ A grande quantidade de sedimentos depositados impediu a determinação da profundidade exacta, bem como de eventuais particularidades do sistema decantador. 


\section{Adução}

O transporte da água potável, desde a nascente mais recuada até ao convento, faz-se por gravidade, em caleiras de pedra calcária abertas com secção transversal semicircular, unidas entre si por encaixe macho-fêmea chanfrado, com argamassa de consolidação e impermeabilização. Este sistema recebe uma forte ou mesmo total influencia dos sistemas hidráulicos da engenharia Romana, na forma como estão descritos no capítulo VIII do livro De Arquitectura de Vitrúvio $^{35}$. Esta influencia revela-se no desenho do traçado que o aqueduto apresenta, nos troços superficiais ${ }^{36}$, em que a conduta acompanha as curvas de nível do terreno, troços aéreos ${ }^{37}$ sempre que este encontra vales profundos, ou por troços soterrados ${ }^{38}$ nas zonas em que as curvas de nível atingem cotas elevadas. É no encontro deste equilíbrio que o traçado está delimitado, originando variações na forma da caleira ora rectilínea ou curva, adaptando-se à sinuosidade do traçado a par com as condutas e galerias.

A volumetria da caleira arquétipo que conduz a água, define-se num prisma rectangular, vazado por uma secção transversal de meia elipse com $0,31 \mathrm{~m}$ no eixo maior e $0,17 \mathrm{~m}$ no eixo menor, tem $1,74 \mathrm{~m}$ de comprimento e a sua largura exterior oscila entre os $0,49 \mathrm{~m}$ e $0,57 \mathrm{~m}$, na espessura mede $0,22 \mathrm{~m}^{39}$. Esta assenta na base da conduta, galeria ou edifício e apresenta variações de secção ao longo do transporte, de forma crescente, de montante para jusante ${ }^{40}$. É imediatamente após a nascente da Porta de Ferro que o eixo menor da elipse da secção da caleira passa a registar 0,30 m evidenciando o aumento do caudal captado neste manancial.

A adução deste sistema hidráulico tem início na nascente do Cano com o transporte da água em caleira, a princípio no interior do edifício, seguindo imediatamente pela galeria soterrada que lhe dá acesso. Daqui segue em conduta até à caixa de decantação ${ }^{41}$ e interligação com o caudal vindo da nascente da

${ }^{35}$ Vitrúvio, "Tratado De Arquitectura", (tradução, introdução e notas de M. Justino Maciel), Lisboa, IST press, 2006, Livro VIII, p. 293-321.

${ }^{36}$ Correspondem a $66,3 \%$ do conjunto, equivalendo a $4.127,46 \mathrm{~m}$, repartidos por quinze troços de comprimento variado, tendo o seu maior troço 738,74 m de extensão e o menor 12,00 m.

${ }^{37}$ Correspondem a 25,6\% do conjunto, equivalendo a $1.596,88 \mathrm{~m}$, repartidos por onze troços de comprimento variado, tendo o seu maior troço no vale dos Pegões com 612,12 m de extensão e o menor com 40,00 m, junto ao lugar de Casal Ribeiro.

${ }^{38}$ Correspondem a $8,1 \%$ do conjunto, equivalendo a $506,66 \mathrm{~m}$, repartidos por cinco troços de comprimento variado, tendo o seu maior troço $310,00 \mathrm{me}$ o menor $31,00 \mathrm{~m}$.

${ }^{39}$ A este propósito, ver em apêndice, Ilustração 10.

${ }^{40}$ Idem, ibidem, Tabela 2.

${ }^{41}$ Este é o primeiro ponto de decantação visualizado que registámos na análise em campo. 
pipa, que, apresenta igual transporte. A partir desta união a água continua em caleira, primeiro num troço superficial que passa a aéreo ${ }^{42}$, seguindo-se novamente outro superficial, agora adaptando-se ao terreno como muro de contenção, até à caixa de decantação no interior do edifício da nascente do Cú-Alagado, sendo aqui a interligação deste manancial com os das anteriores nascentes. A adução deste caudal até à nascente da Porta de Ferro realiza-se maioritariamente em conduta sob troço superficial tendo dois troços aéreos e um soterrado com galeria para a devida manutenção, cujo acesso é feito por um poço de visita no ultimo troço superficial antes da nascente, este com arcadas na base para a passagem das águas da ribeira que atravessa. Assim é realizada a passagem de conduta a galeria permitindo o acesso à limpeza da caleira e caixas de decantação nas zonas soterradas ${ }^{43}$.Captada a água das 4 nascentes o transporte segue ao longo da rede adutora ${ }^{44}$ até ao convento, com igual abordagem construtiva, interceptando o terreno com o tipo de troço que melhor se adapta às circunstancias do funcionamento do sistema adutor, com a caleira em conduta ou galeria, tendo sempre presente a actividade no vale, linhas de água, zonas de passagem de gado e vias de comunicação.

$\mathrm{O}$ interior da rede adutora nos troços soterrados e superficiais, apresenta variações de dimensionamento na conduta ou galeria, consoante as necessidades técnicas necessárias ao bom funcionamento do transporte da água. $\mathrm{O}$ exterior da conduta apresenta uma largura constante de 1,50 m em quase todo o traçado, sendo variável a altura das suas paredes na intersecção do terreno. O dimensionamento das placas de calcário que cobrem a conduta corresponde a 0,70 X 0,70 m e 0,15 m de espessura. Nos troços aéreos o volume da conduta adopta a largura exterior do troço, excepto nos de maior dimensão em que na largura do topo do troço é reservado espaço para a circulação, permitindo desta forma a sua manutenção periódica.

A galeria difere da conduta pelo aumento da altura interior que possibilita o acesso às nascentes, e aos troços soterrados para a devida manutenção da caleira e das caixas de decantação. A altura interior é variável, dependendo da pendente, e a largura corresponde aproximadamente a $0,70 \mathrm{~m}$. O seu comprimento é variado, sendo a maior extensão de 310,00 m, no troço soterrado que antecede

${ }^{42}$ É claro que neste troço, as arcadas são introduzidas na construção para permitir a passagem das águas superficiais que geram o início da ribeira do choupal.

${ }^{43}$ A este propósito, ver em apêndice, Ilustração 3, 4, 5 e 6.

${ }^{44}$ No percurso da adução foi registado em diversas zonas, o acrescento de silhares sobre a caleira, ganhando assim maior capacidade de caudal. 
o edifício de decantação na Cadeira d'El $\operatorname{Rei}^{45}$ e a menor de $31,00 \mathrm{~m}$, na galeria de acesso à nascente da Pipa ${ }^{46}$. Os acessos às galerias ${ }^{47}$ são maioritariamente realizados através de poços de visita, tendo sido registados ao longo de todo o conjunto 10 exemplares. Estes têm um desenho rectilíneo de secção quadrada onde a espessura das suas paredes coincide com a das paredes laterais da galeria.

A necessidade de dispositivos de depuração da água revela-se em todo o percurso adutor, sendo a sua presença uma constante na base dos poços de visita às galerias nos troços superficiais, nos edifícios das nascentes ou nas casas de decantação e fresco. É aqui que estas ganham maior visibilidade com os tanques de decantação localizados no centro do edifício, de forma ortogonal. O local onde a depuração assume maior destaque, para além do megatanque trapezoidal da nascente da Porta de Ferro, situa-se na casa de fresco a jusante do troço aéreo dos Pegões ${ }^{48}$, com o desenho do interior do espaço, marcado com a rotação do quadrado (tanque) dentro do quadrado (planta interior). Refira-se que este edificado é um marco no todo do conjunto, cuja pureza do desenho ${ }^{49}$ volumétrico identifica inequivocamente o círculo como matriz geradora da composição arquitectónica ${ }^{50}$.

Os restantes edifícios com sistema depurativo como o da nascente do Cú-Alagado, da casa de fresco a montante dos Pegões e a que encontramos no sitio da Cadeira d'EL Rei, tem o mesmo tipo de desenho, reflectido na volumetria de um cubo rematado por uma cobertura de meia esfera, com variações quanto às dimensões e aos vãos que apresentam ${ }^{51}$.

Sobre a rede de distribuição, referimos a necessidade urgente de trabalhos arqueológicos, pois os conhecimentos apurados são inconclusivos. Em todo o caso julgamos importante referir os conhecimentos indagados no trabalho de campo. No traçado exterior à cerca conventual, encontram-se dois tanques para rega, um ligado à conduta de transporte de água, entre o poço de acesso à nascente da Pipa e a nascente do Cú-Alagado e outro junto à nascente da Porta

${ }^{45}$ A este propósito, ver em apêndice, Ilustração 9.

${ }^{46}$ Idem, ibidem, Ilustração 4.

${ }^{47}$ Verificámos o acesso a galeria por vão lateral em dois troços, um realizado exclusivamente para a decantação, localizado imediatamente antes do troço aéreo que antecede o troço dos Pegões e outro num troço soterrado que permite o acesso à cerca conventual, pelo lugar da Cadeira d'El Rei.

${ }^{48}$ A este propósito, ver em apêndice, Ilustração 7.

${ }^{49}$ No revestimento estucado da abóbada hemisférica interior, registámos um desenho geométrico com ovais e losangos, inseridas num conjunto de linhas dispostas de forma radial, que atravessam as várias circunferências concêntricas, reforçando a imagem volumétrica interior.

${ }^{50}$ A este propósito, ver em apêndice, Ilustração 8.

${ }^{51}$ Idem, ibidem, Ilustração 5, 7 e 9. 
de Ferro $^{52}$, ambas as zonas extensamente ocupadas por horta, que em alturas de seca seriam uma mais valia para agricultura fora da $\mathrm{Cerca}^{53}$. Outro aspecto da distribuição da água foi-nos transmitido pelos habitantes locais mais antigos, que nos elucidaram sobre um pequeno tanque adossado à conduta, a montante do troço aéreo dos Pegões, que serviu em tempos remotos para dar de beber aos animais que transportavam carga, sendo que a jusante existiu outro.

Os circuitos de distribuição da água no interior da Cerca e do Convento, bem como a sua evacuação, não são descritos aqui, por ultrapassarem os objectivos deste estudo, no entanto, julgamos importante apontar que a distribuição da água dentro da cerca conventual, faz-se no lugar da cadeira d'El Rei ${ }^{54}$, para o tanque que distribui a água para rega da cerca, para o lagar de azeite (hoje em ruína) adossado ao ultimo troço aéreo do conjunto, e, para o sistema hidráulico do Convento de Cristo, onde a fonte do claustro dos Filipes tem a sua maior clarividência.

Os materiais usados na construção da rede adutora e dos edifícios de decantação na adução são a alvenaria de pedra ordinária argamassada, com a excepção dos cunhais que apresentam o aparelho de cantaria regular. No interior o revestimento é realizado em reboco, tendo visíveis as peças de cantaria nas aduelas dos vãos, nos tanques de depuração, no pavimento e na imposta que circunda e suporta a abóbada hemisférica das coberturas. A cobertura das condutas e galerias em placas de calcário são revestidas de reboco nas extremidades laterais, rematadas de forma curvilínea com a função de escoar as águas pluviais da mesma forma com que são rematados os topos das paredes dos poços de acesso às nascentes e galerias.

\section{Considerações finais}

O contacto com este aqueduto revelou-nos a perícia da tecnologia de construção dos seus arquitectos e mestres-pedreiros, bem como o avançado conhecimento dos sistemas hidráulicos que o aqueduto do Convento de Cristo ainda hoje conserva bastante intactos. Pelos dados apresentados verifica-se que a logística de materiais entregues em obra é metódica e coincidente com

${ }^{52}$ Onde o tanque de decantação tem um descarregador de superfície para a um sistema de rega que se interliga com a ribeira do Choupal.

${ }^{53}$ A este propósito, ver António de Carvalho Quintela, "Breve caracterização das obras hidráulicas e da utilização da água em Portugal anteriormente ao século XVIII", in José Manuel Mascarenhas, M. H. Abecasis e V. F. Jorge (ed.), Actas do Simpósio Internacional Hidráulica Monástica Medieval e Moderna, Lisboa, Ed. da Fundação Oriente, 1996, p. 15-34.

${ }^{54}$ A este propósito, ver Ilustração 9. 
os contratos realizados para esta, o que nos permite afirmar que a execução da construção do aqueduto, embora faseada, é contínua em toda a sua extensão.

Sobre o traçado deste sistema hidráulico acrescentamos o reconhecimento integral do conjunto alcançado através do trabalho de campo realizado, que nos permite concluir quatro aspectos deste conjunto. O mais importante é que apesar do avançado estado de degradação, o traçado está consolidado e toda a edificação está íntegra, o que permite a sua conservação. O segundo diz respeito ao equilíbrio que encontramos nas opções da tipologia de troços adoptados que apontam a redução do volume da construção sempre que possível. Outro aspecto revela-se no ajuste entre a inclinação e a capacidade de transporte hídrica representado no abrandamento da velocidade com o aumento do caudal, que após a captação dos quatro mananciais, estabiliza o declive a $0,2 \%$, o que nos identifica o controlo na execução e montagem da caleira em todo o traçado. Outro ainda, não menos importante, corresponde à interacção que o conjunto tem com a actividade do vale da ribeira do Choupal.

A execução das minas e as diferentes captações de água são similares às tipologias já estudadas ${ }^{55}$ do Sistema Hidráulico do Convento Dominicano de Santa Maria da Vitória, na Batalha. O transporte em conduta ou galeria (aberta em trincheira) é comum nos sistemas hidráulicos em ambiente monástico ou conventual, como São João de Tarouca, São Bento de Cástris, em Évora e a rede hidráulica do Convento Franciscano de Varatojo, em Torres Vedras ${ }^{56}$. A grande quantidade de caixas e tanques de decantação no percurso adutor reflecte a necessidade de depuração da água, o que espelha a qualidade deste recurso na vida conventual.

Os registos da estrutura hidráulica, que aqui apresentámos em síntese são uma ferramenta preliminar, útil à intervenção de conservação e salvaguarda do património edificado, na protecção e valorização da identidade cultural deste aqueduto e da sua envolvente, cuja relação é intrínseca.

Recebido em/Text submitted on: 16/04/2012

Aceite em/Approved on: 13/05/2012

${ }^{55}$ A este propósito, ver Virgolino Ferreira Jorge, "Sistema Hidráulico do Convento Dominicano de Santa Maria da Vitória (Batalha)", in José Manuel Mascarenhas, M. H. Abecasis e V. F. Jorge (ed.), Actas do Simpósio Internacional Hidráulica Monástica Medieval e Moderna, Lisboa, Ed. da Fundação Oriente, 1996, p. 105-125.

${ }^{56}$ A este propósito, ver José Manuel de Mascarenhas, Joséphine Rouillard; Karine Berthier; Paul Benoit e Virgolino Ferreira Jorge, "A Exploração dos Recursos Hídricos no Convento Franciscano de Varatojo (Torres Vedras)", Separata do Boletim Cultural da Assembleia Distrital de Lisboa, Série IV, n. $.^{\circ} 95,2 .^{\circ}$ tomo, 2009, p. 37-54. 
Apêndice

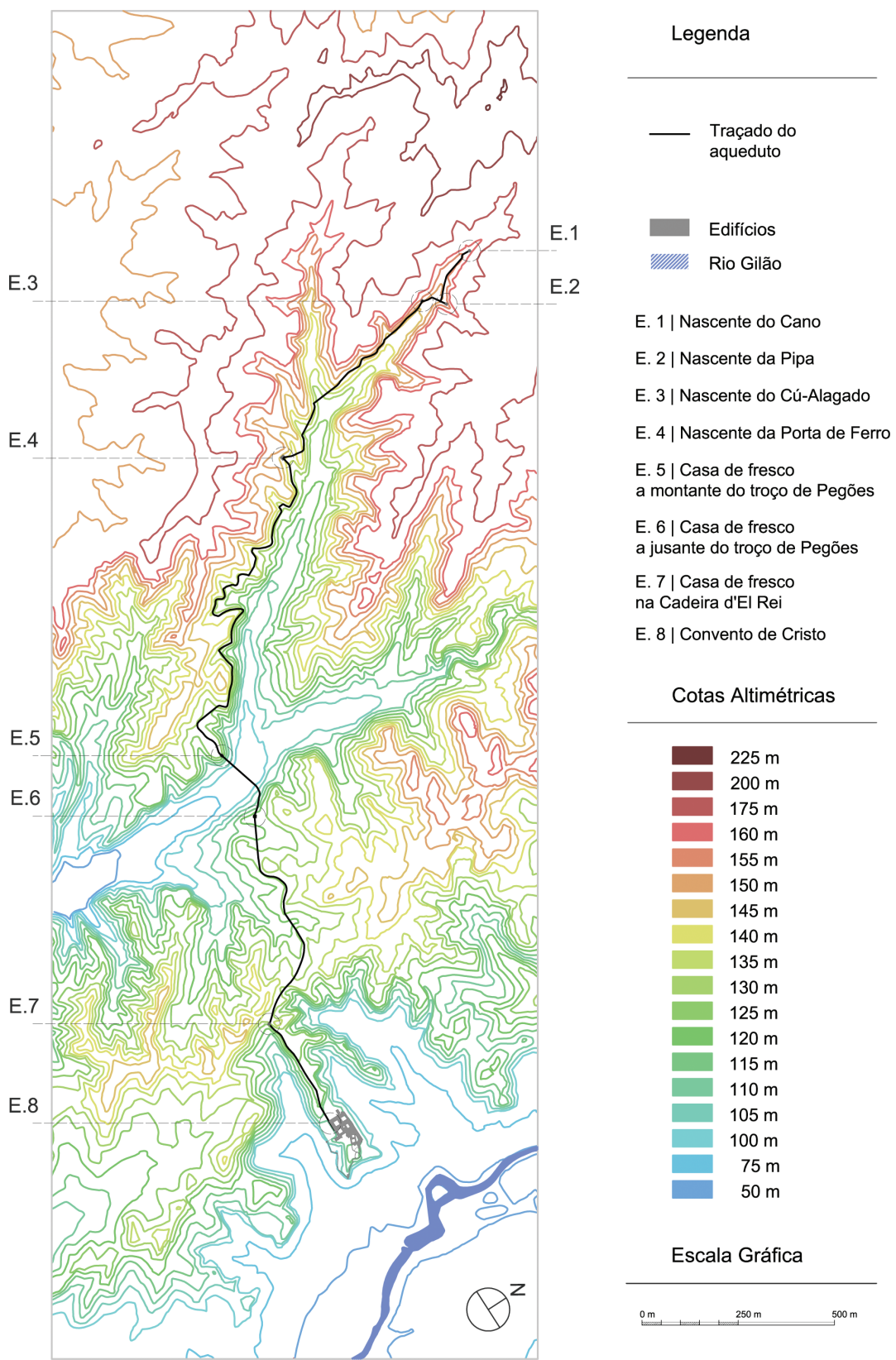

Ilustração 1 - Reconhecimento do aqueduto na morfologia do terreno. 


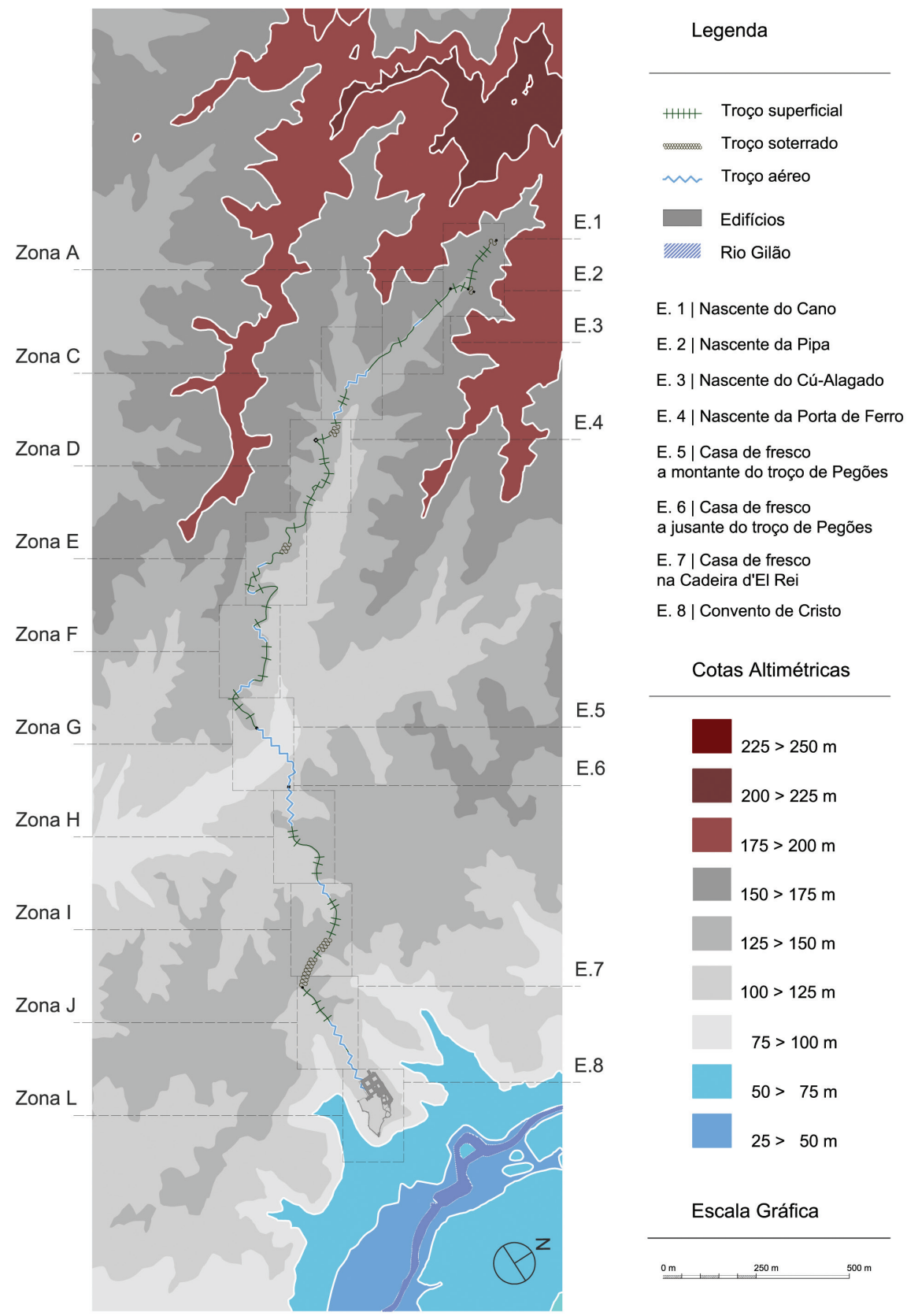

Ilustração 2 - Identificação das tipologias de troços do aqueduto e localização das zonas de levantamento e inspecção. 


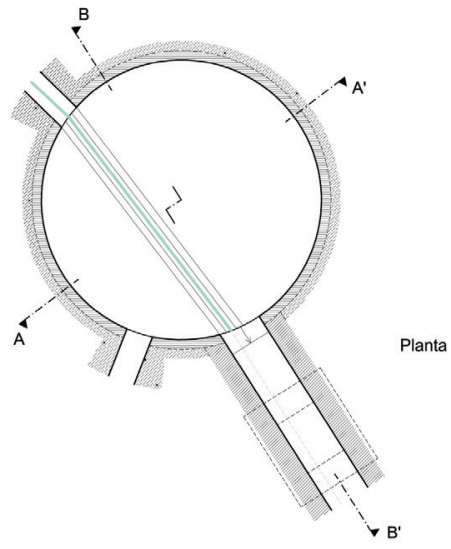

Localizaçăo da Zona A | sem escala

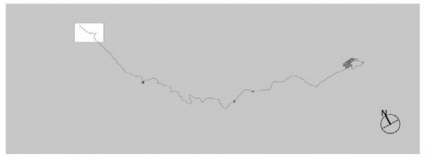

Modelo gráico de localização da Zona A | 1:5000
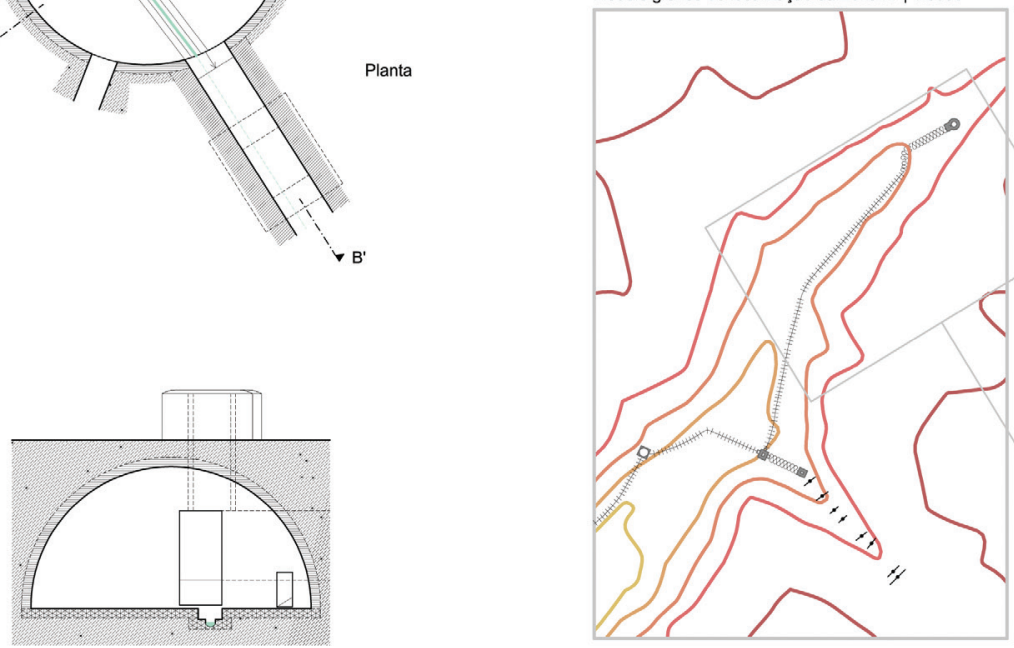

Corte A A'

Fotografia aérea | 1957
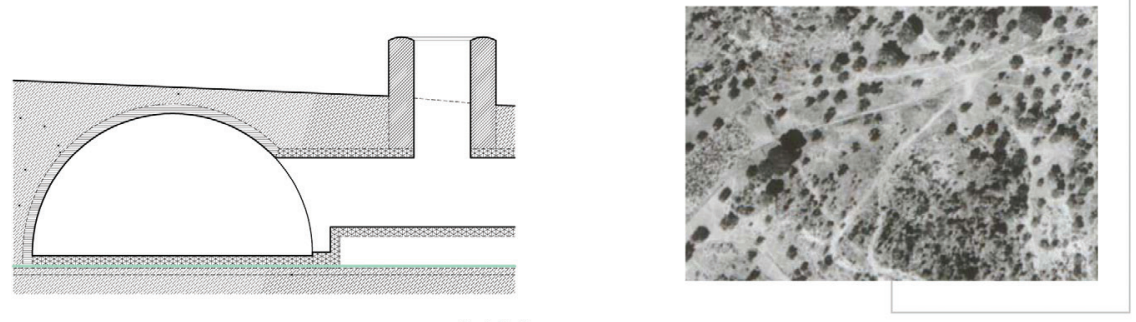

Corte B B'

Nota: E .1 | Levantamento de Virgolino Jorge

\begin{tabular}{|c|c|c|c|c|c|c|}
\hline \multirow[t]{2}{*}{ Legenda } & \multirow{2}{*}{$\overrightarrow{0}$} & \multirow{2}{*}{$\begin{array}{l}\text { Drenos de captaçăo de águas pluviais } \\
\text { E. } 1 \text { | Nascente do Cano }\end{array}$} & \multirow{2}{*}{$\begin{array}{c}\text { Cotas Altimétricas } \\
175 \mathrm{~m}\end{array}$} & \multicolumn{2}{|c|}{ Escalas Gráficas } & \\
\hline & & & & Zona A & & \\
\hline Hinititi+ Troço superficial & 維䋞 & solo & $160 \mathrm{~m}$ & & (50mi & $2305 \mathrm{~m}$ \\
\hline roxoso Troço soterrado & 3/I- & Alvenaria ordinária & $150 \mathrm{~m}$ & E. 1 & $0 \mathrm{~m}$ & $5 \mathrm{~m}$ \\
\hline & & & $145 m$ & & & \\
\hline Troço aéreo & 36 & Alvenaria de pedra aparelhada & & & & \\
\hline _ Linha de água do Aqueduto & $\underline{\underline{\underline{\underline{\underline{\underline{E}}}}}}$ & Alvenaria de tijolo aparelhado & & & & \\
\hline
\end{tabular}

Ilustração 3 - Edifício 1 - Nascente do Cano, levantamento. 


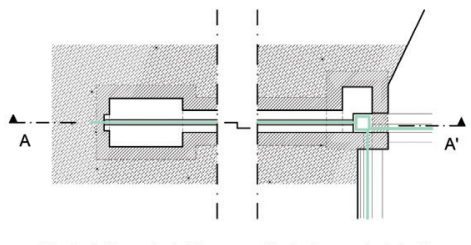

Localização da Zona A | sem escala

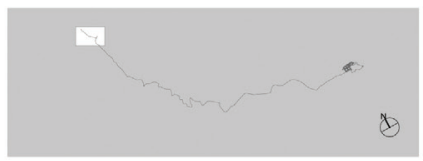

Planta da Nascente da Pipa Planta do poço de visitação



Poço de visitação da Nascente da Pipa | Alçados
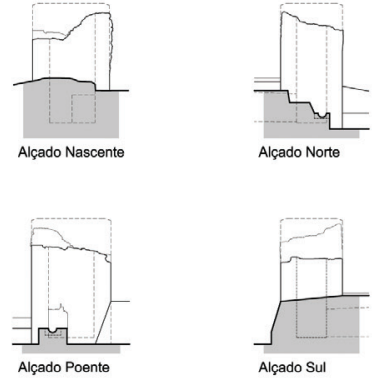

Fotografia aérea | 1957

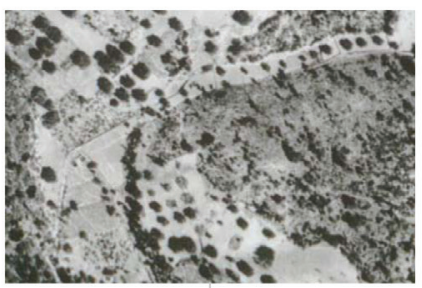

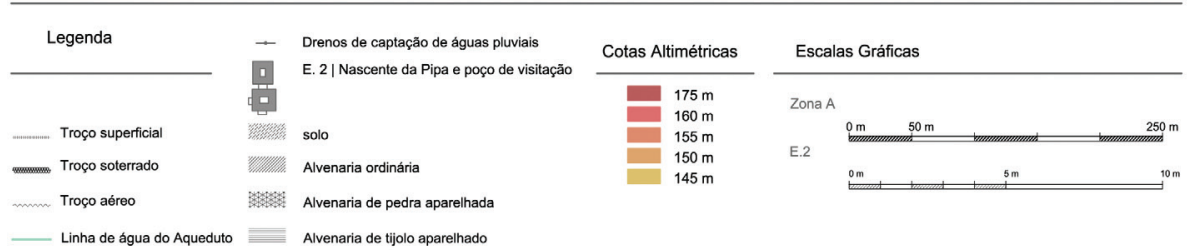

Ilustração 4 - Edifício 2 - Nascente da Pipa, levantamento. 


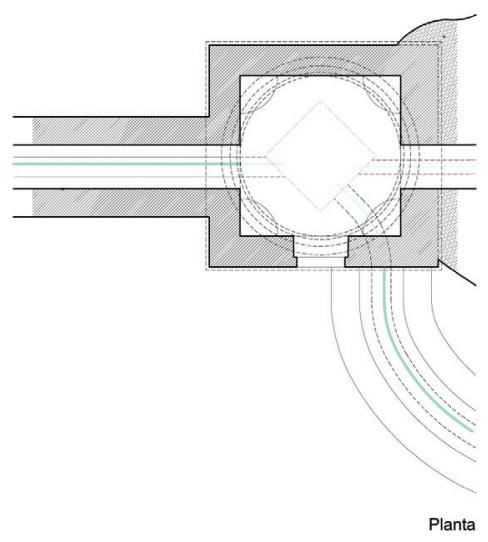

Localização da Zona A | sem escala

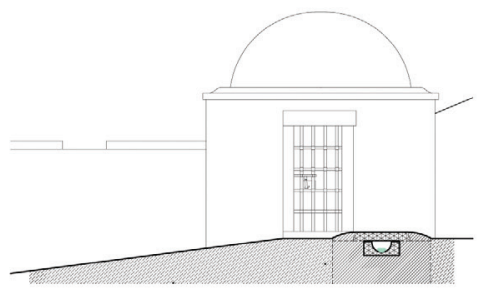

Alçado nascente

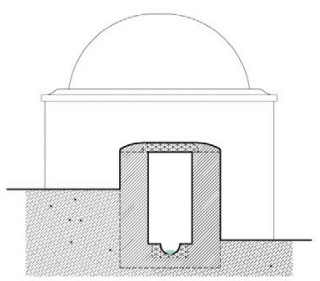

Alçado sul

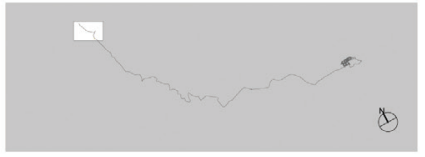

Modelo gráfico de situação do Edificio 3 | Zona A | 1:5000

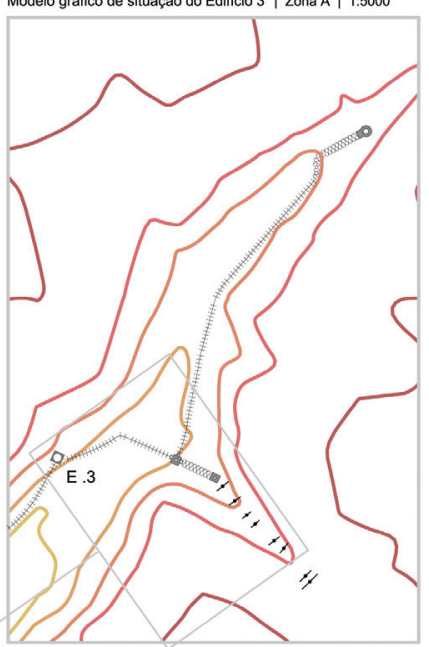

Fotografia aérea | 1957

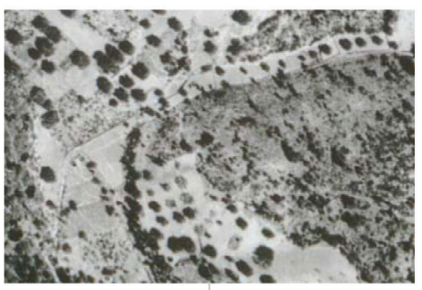

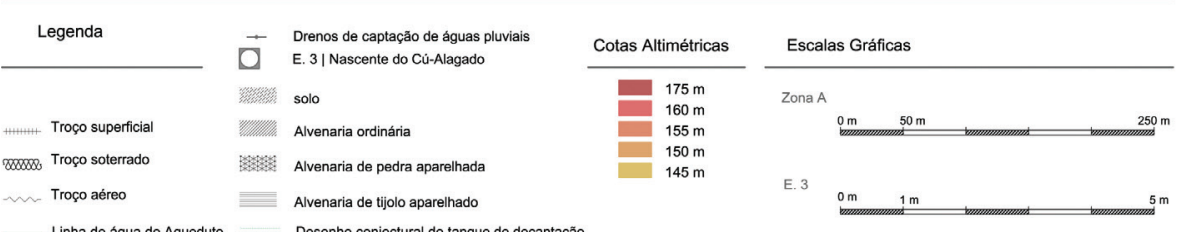

Ilustração 5 - Edifício 3 - Nascente do Cú-Alagado, levantamento. 


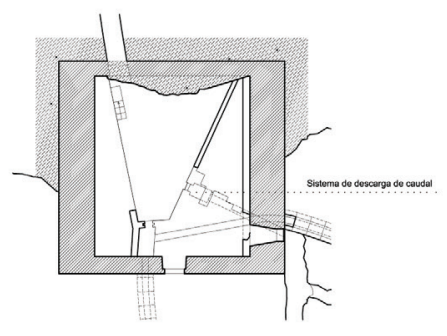

Localização da Zona G | sem escala

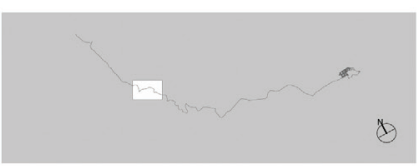

Modelo gráfico de situação do Edificio 4 | Zona D | 1:5000

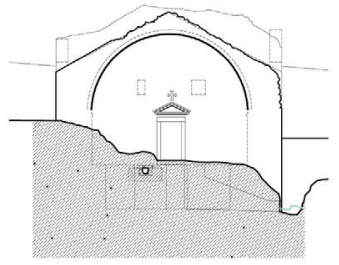

Planta

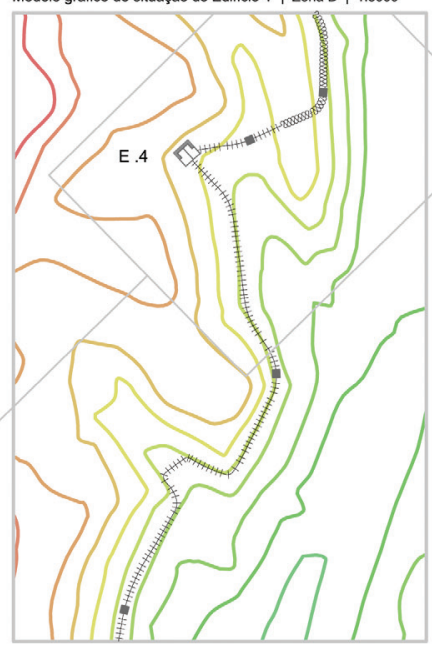

Alçado frontal

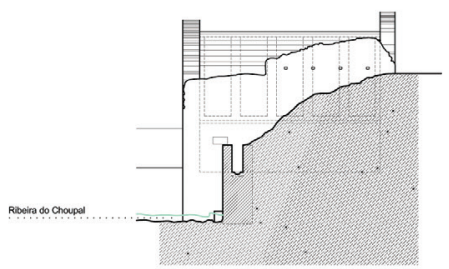

Fotografia aérea | 1957

Alçado lateral Nascente

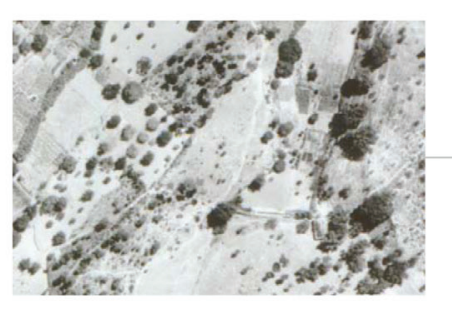

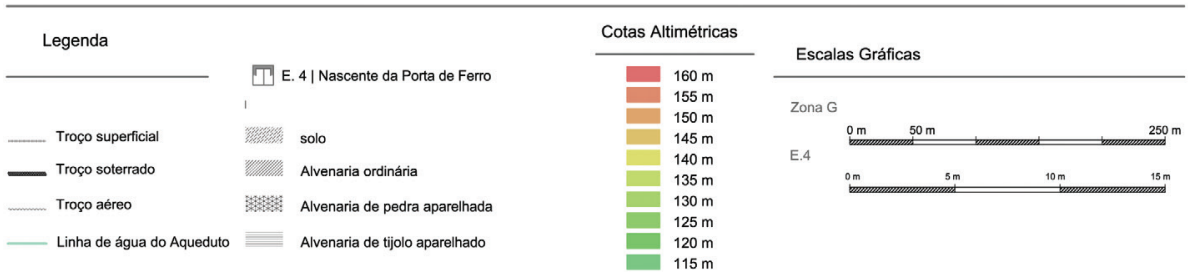

Ilustração 6 - Edifício 4 - Nascente da Porta de Ferro, levantamento. 


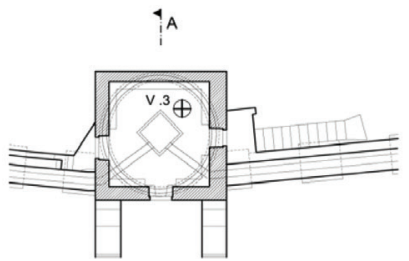

Localizaçăo da Zona G | sem escala
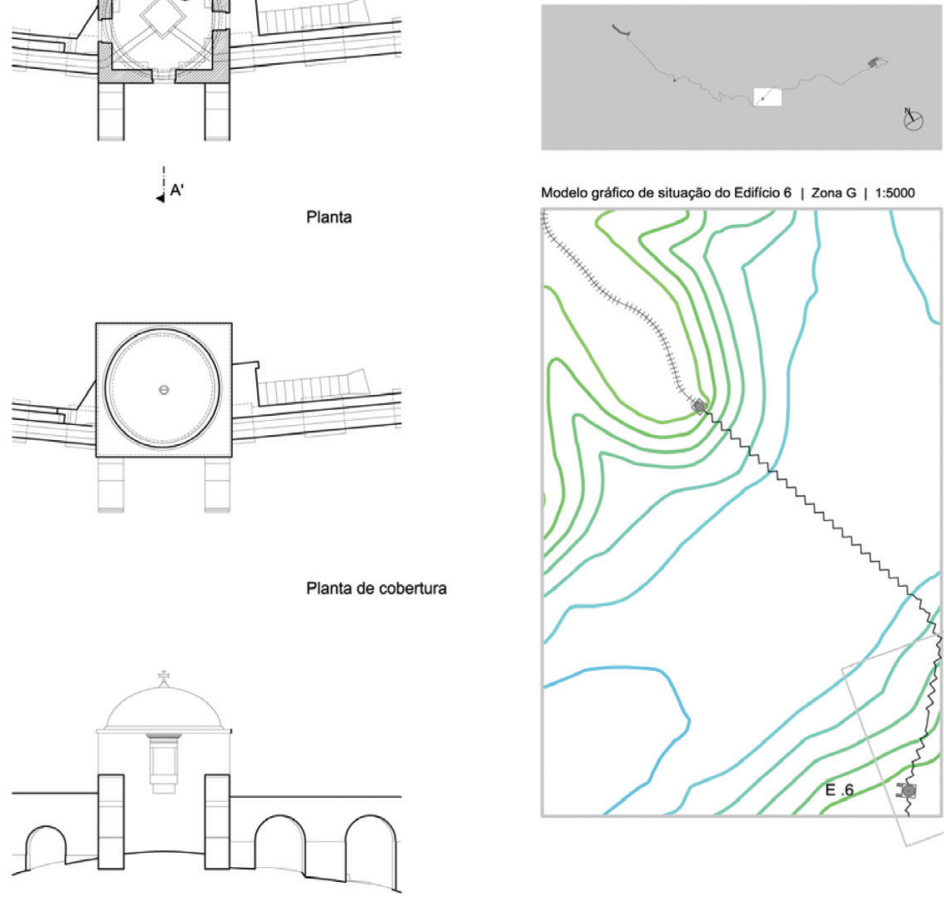

Modelo gráfico de situaçāo do Edificio 6 | Zona G | 1:5000
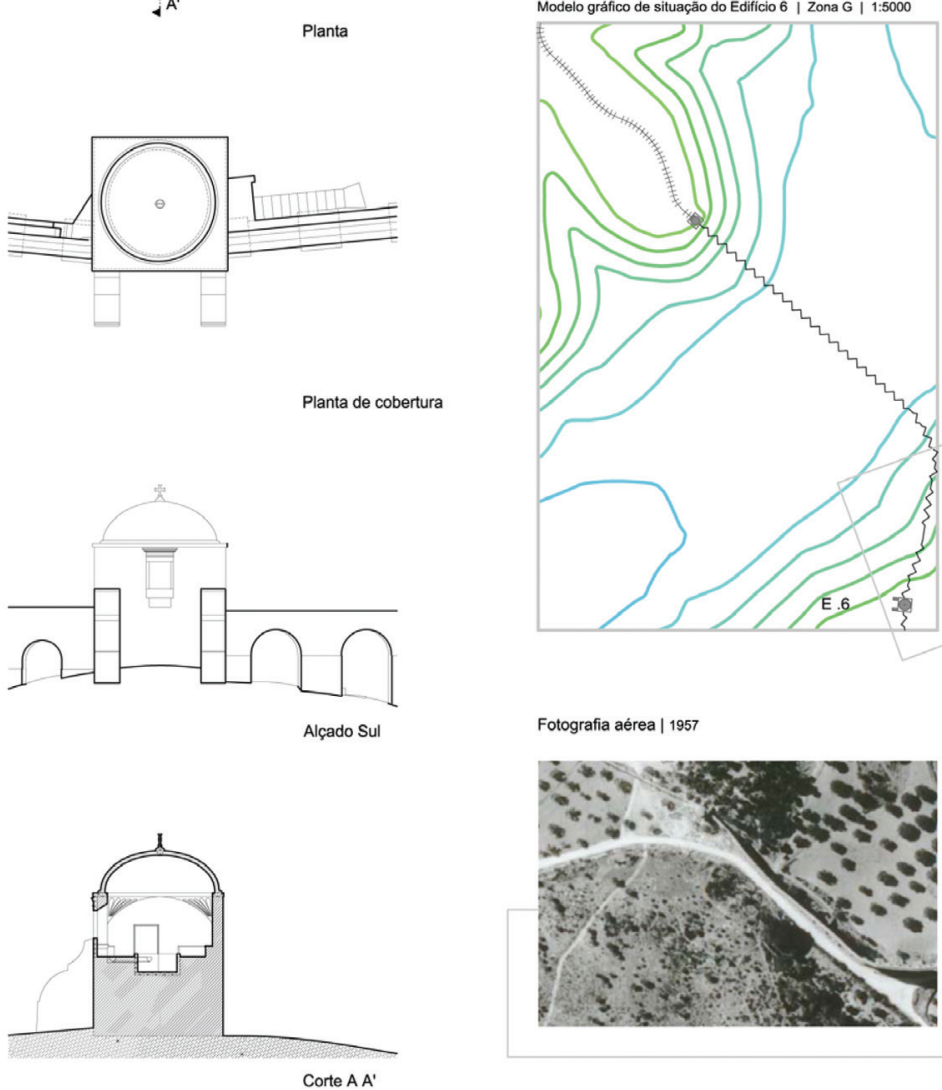

Fotografia aérea | 1957

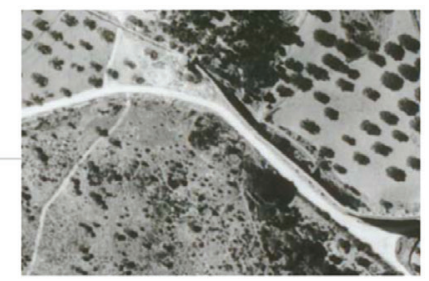

Corte A A

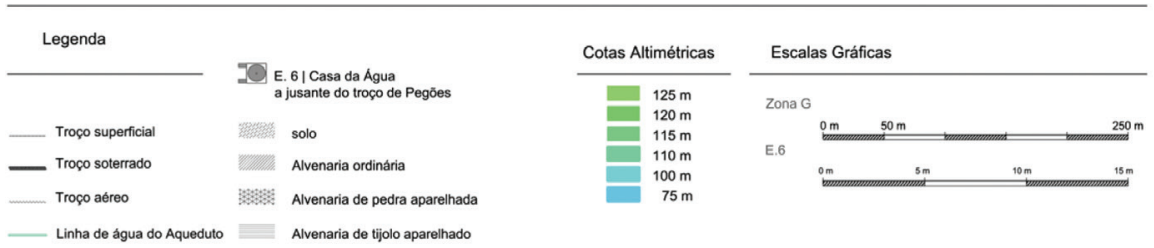

Ilustração 7 - Edifício 6 - Casa de fresco a jusante do troço aéreo dos Pegões, levantamento. 

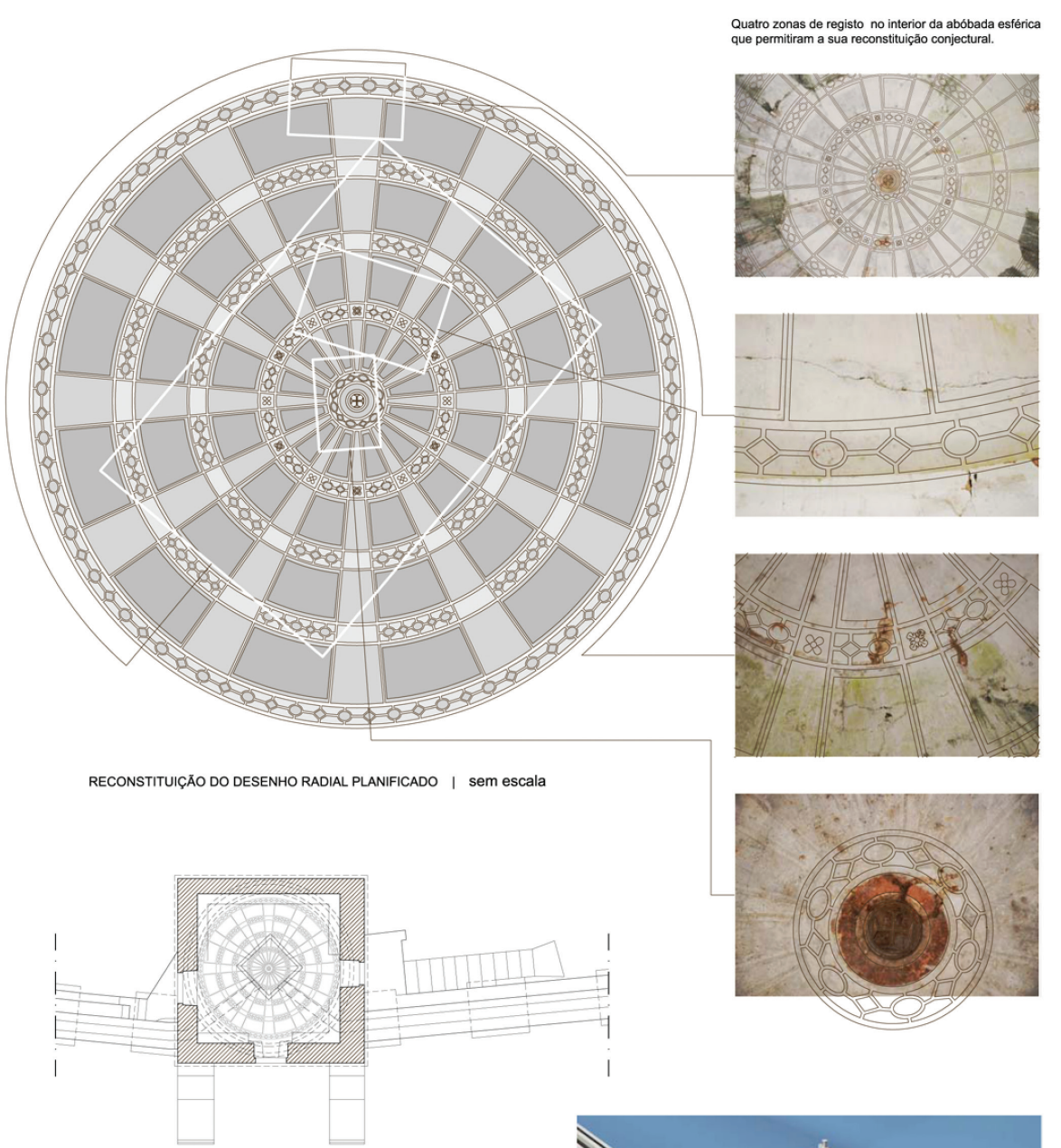

Localizaçăo da cobertura | EDIFicıO 6 | sem escala

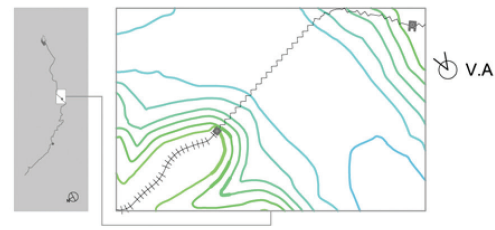

Localização da Zona G / Edifício 6 | sem escala

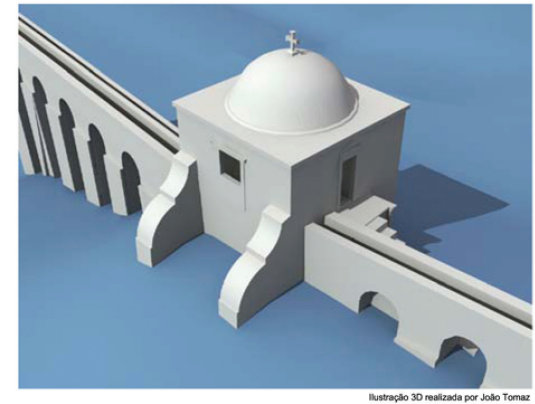

\& Vista .A | Edificio 6

Ilustração 8 - Edifício 6 - Reconstituição da abóbada hemisférica da casa de fresco a jusante do troço aéreo dos Pegões. 


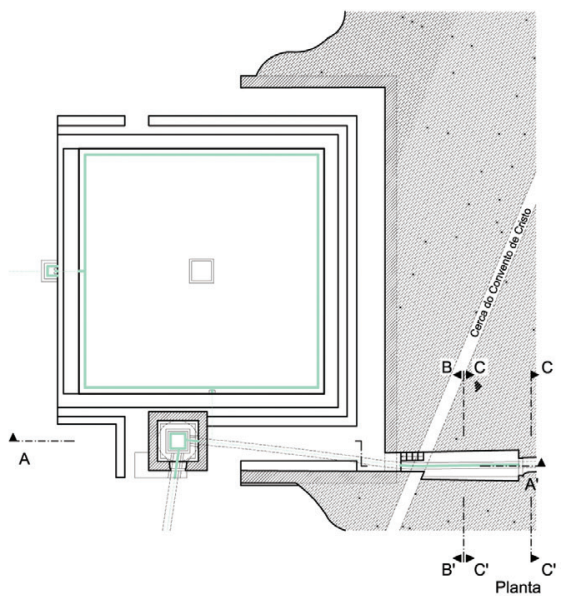

Localização da Zona J | sem escala
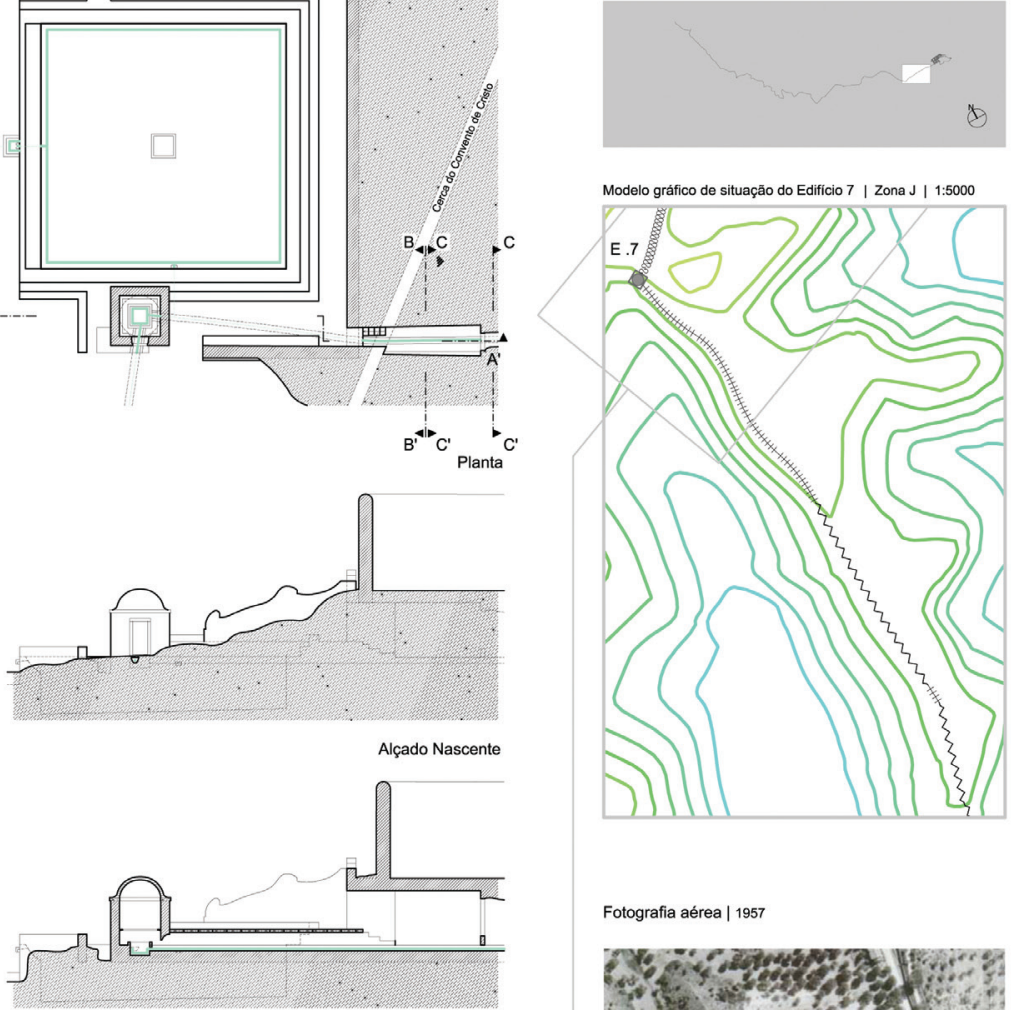

Corte A A'

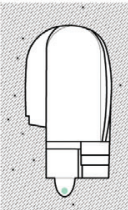

Corte B B

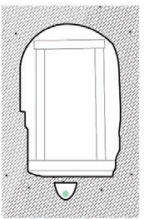

Corte C C'

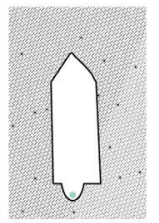

Corte D D'
Fotografia aérea | 1957

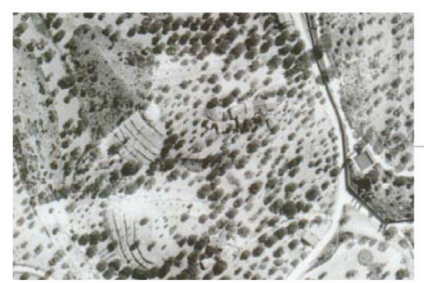

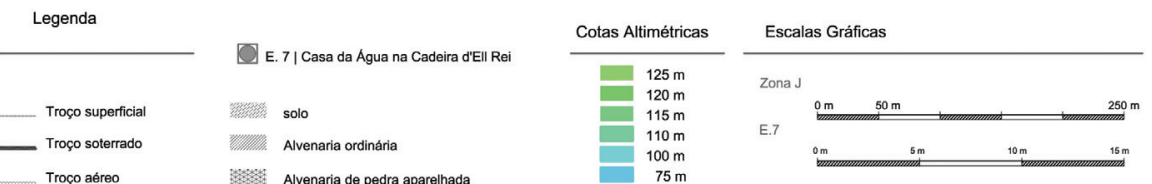

Ilustração 9 - Edifício 4 - Casa de fresco na Cadeira d'El Rei, no interior da Cerca Conventual. 

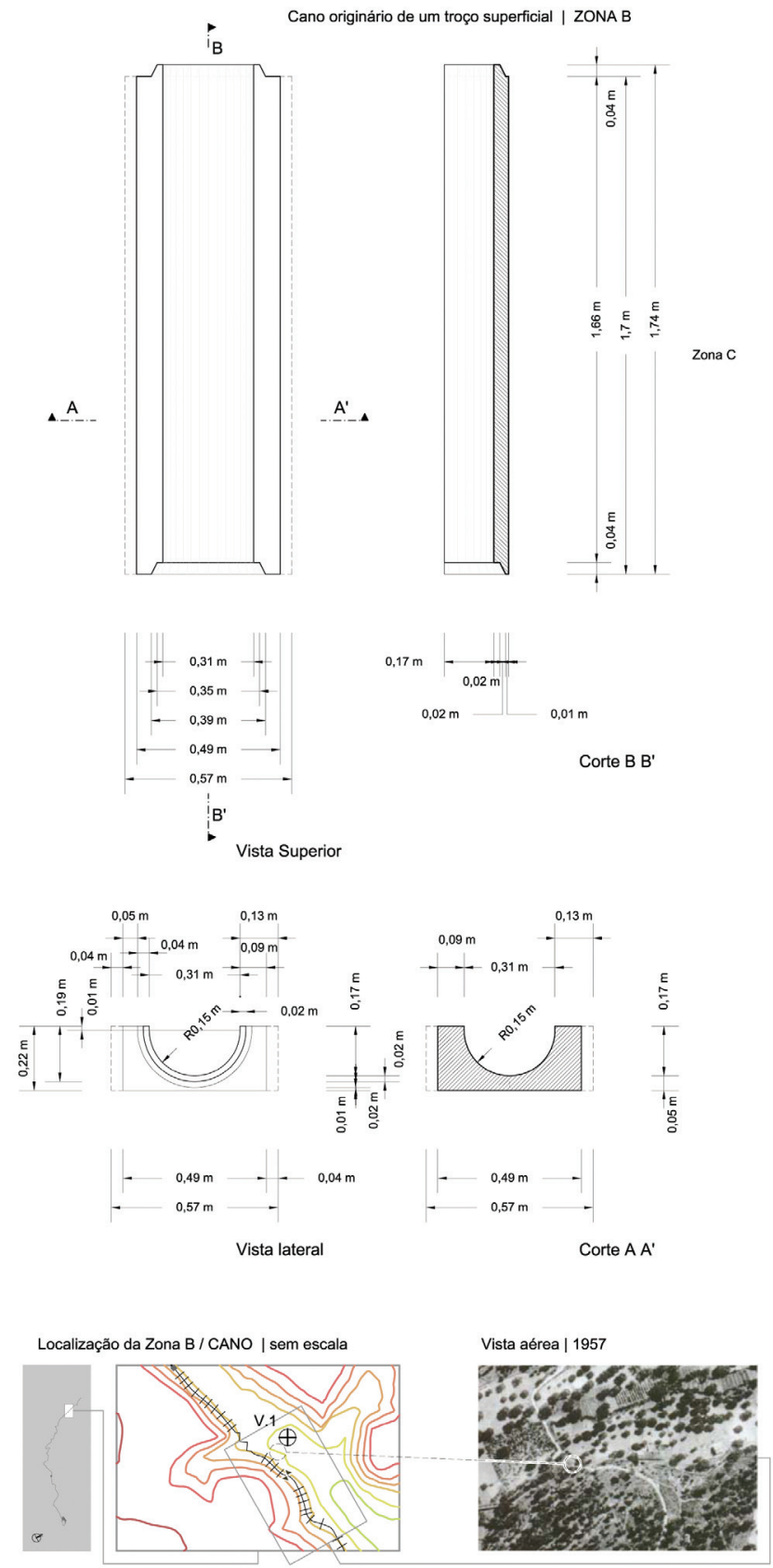

Ilustração 10 - Levantamento de um cano primitivo, originário de um troço superficial na Zona B 
Percentagens do declive da conduta na extensão linear, no aqueduto do Convento de Cristo em Tomar.

\begin{tabular}{|l|c|c|c|c|c|c|c|c|c|c|c|}
\hline $\begin{array}{l}\text { Situação dos registos } \\
\text { do declive da conduta }\end{array}$ & Zona A & Zona B & Zona C & Zona D & Zona E & Zona F & Zona G & Zona H & Zona I & Zona J & Zona L \\
\hline Extensão linear & 491,72 & 496,68 & 448,93 & 676,24 & 957,27 & 665,86 & 640,17 & 590,49 & 568,85 & 588,85 & 131,00 \\
\hline $\begin{array}{l}\text { Diferença entre as cotas } \\
\text { altimétricas na intersecção } \\
\text { da conduta por zona }\end{array}$ & 5,10 & 7,66 & 2,75 & 2,50 & 2,04 & 1,42 & 1,36 & 1,26 & 1,21 & 1,25 & 0,27 \\
\hline $\begin{array}{l}\text { Declive percentual } \\
\text { por cada 100 m }\end{array}$ & $1 \%$ & $1,5 \%$ & $0,6 \%$ & $0,3 \%$ & $0,2 \%$ & $0,2 \%$ & $0,2 \%$ & $0,2 \%$ & $0,2 \%$ & $0,2 \%$ & $0,2 \%$ \\
\hline $\begin{array}{l}\text { Notas: } \\
\text { Os valores apresentados são em metros. }\end{array}$
\end{tabular}

Tabela 1 - Sistematização da média dos valores percentuais do declive na adução do aqueduto do Convento de Cristo em Tomar.

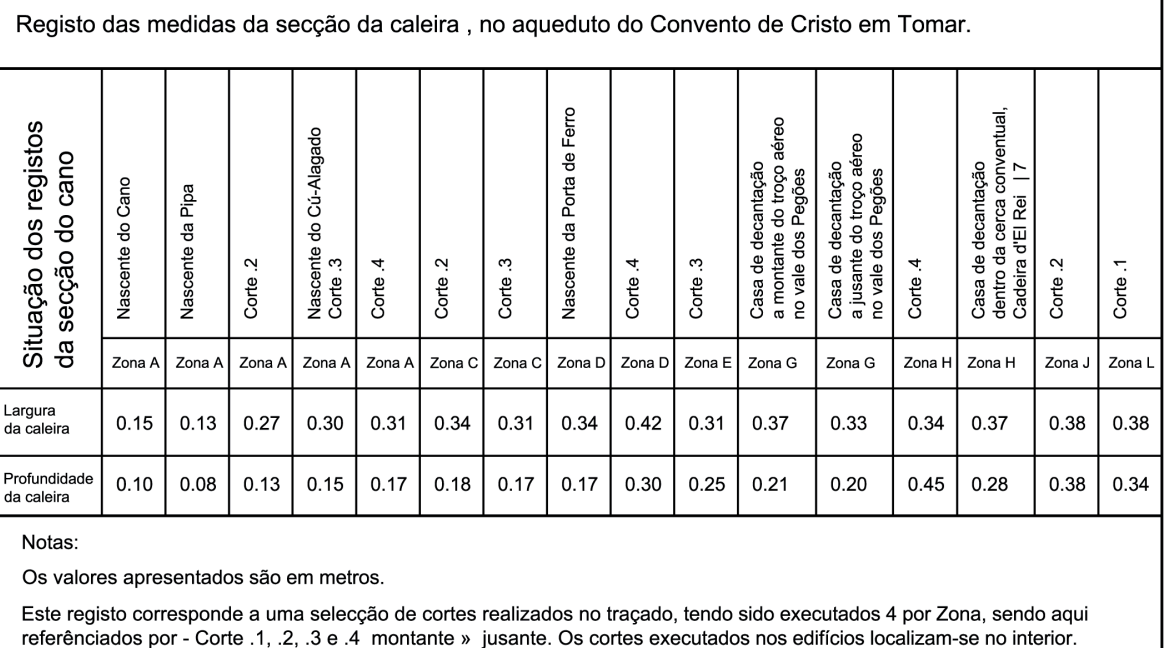

Tabela 2 - Sistematização de uma selecção de secções da caleira que apresenta a variação de dimensões no percurso adutor do aqueduto do Convento de Cristo em Tomar. 